\title{
Microfilm in the Small College Library
}

Mr. Paine, librarian, Beloit College Library, presented this paper at a meeting of the College Libraries Section of the Association of College and Reference Libraries, December 29, I94I.

$\mathrm{D}$ ESPITE - recent marked advances in microphotography and microprint techniques, the time when a student or faculty member will come to the loan desk of the college library to borrow Berlin Diary for home reading and go out with a three-inch reel of sixteen or thirty-five millimeter film or a three by five card size microprint edition, is far distant. There is nothing yet to replace a real paper book for reading one's self to sleep, despite the promises of at least one company to bring out a special projector to hang over the bed.

A review of the literature which has appeared in the field of photographic reproduction and projection as it concerns the librarian through the period of 19364 I reveals some 450 articles, with no more than three or four purporting to consider microfilm from the standpoint of the small college library. Nor, for that matter, are there more than a very few having to do with administrative problems in any library. Most of the literature thus far has been in the field of technical developments. This is a natural trend in a technical field in which developments, if not origins, are so recent. Those who are most active in the field are either photographic technicians or librarians who have become interested in the technical developments to the exclusion, for the time being at least, of the administrative aspects.

What Herman Fussler wrote in 1938 is apparently still true:

Much time on the part of librarians has been spent during the past few years in dealing with purely technical matters. If microphotography as low-priced reproduction is really to fulfill its apparent potentialities, there must be some bed-rock planning and consideration first, and the librarians must assume the obligation, for investigators are too much concerned with their own individual subject fields to consider scholarly documentation as a whole. The technicians, likewise, have neither the knowledge nor the inclination to direct the path of the new technique.... 1

If we may judge from the literature on the subject which followed, college librarians did not take up this challenge. It was our belief that only research institutions could afford this luxury. Nor was this concept of microphotography as a luxury entirely without grounds, for turning again to Mr. Fussler, we find "If $\$ 50$ is invested, the results may be worth that amount, but ... they will, of course, not be what a laboratory costing $\$ 5000$ or

1 Fussler, H. H. "College Microfilming and Equip. ment. ..." A.L.A. Bulletin 32:820-22, Oct. I 5, I 938 . 
more can produce."2 As if this mention of some figure lying vaguely between $\$ 50$ and $\$ 5000$ were not sufficient to frighten any budget-conscious college librarian, $\mathrm{Mr}$. Fussler goes on to list cameras with supplementary lens, home-rigged copying stand, developing tank, hand viewer or semi-home-rigged projector, and a few accessories such as bottles, safe light, balance, a graduate, fifty-foot capacity reels, three mixing tanks, Stineman reels, printers, enlargers, splicers, rewinders, etc. This was the technician, trying valiantly to interest the college librarian in embarking upon a microfilm program in his library. No one has contributed more to technical knowledge of microphotography for libraries than Mr. Fussler, but apparently the information which he has given us has fallen upon deaf ears.

\section{Recognition for the College Library}

Of the few authorities on college library administration who have produced books on that subject during this five-year period, Miss McCrum, in 1937, is the only one who, to my knowledge, has granted microphotography any recognition as a legitimate part of the college library. ${ }^{3}$

For the most part, in the literature of college librarianship and microphotography there are to be found only a few highsounding generalities such as "For as the gift of Gutenberg brought many books within the reach of many men, so any book may come to any library through the medium of the microphotograph."

The chief difficulty seems to have been the belief that microphotography and the use of microfilm were inseparable. Of the

2 Fussler, H. H. "Microphotography for Smaller Libraries." A.L.A. Bulletin 31:41-42, Jan. 1937. 3 McCrum, B. P. An Estimate of Standards for a College Library. Journalism Laboratory Press, 1937, p. 132 . former it has been said, "Reproduction of such material on request is, of course, selfsupporting and therefore not a liability to the library but a definite asset to prestige." That it would be the latter I do not doubt, but considering the small volume of such reproduction which would be called for from the average college library and that the original cost of the reproduction equipment and laboratory must be amortized, the field of microphotography is not one in which any of us can afford to indulgeto charge off an expenditure of several thousand dollars, or even several hundred, to the prestige account is apt to bring the auditors on the run.

\section{Separation of Microphotography and Microfilm}

Even Miss McCrum failed to recognize that microphotography and the use of microfilm can be separated insofar as library administration is concerned. In the "checklist of building requirements" which she appended to her book, there is no entry under microfilm, but under microphotography we find "... Space and equipment for making and using film and photostats. Plumbing for developing room. Provide for growth in this department."

More fanciful authors have gone so far as to suggest to the college librarian the filming of the card catalog as economy of space and insurance against loss by fire or flood. Even at a minimum cost of one half cent per card, this would seem to be rather expensive insurance when we figure the chances of destruction of the card catalog, by these or other means, especially when the film copy would be out-dated before it was ever completed. Moreover, recent experiments and developments in a microphotographic charging system, 
though undoubtedly practical in some situations, are not steps which the average college library can justify.

Such schemes, along with the failure of most authorities to distinguish between microphotography, with its expensive equipment and laboratories, and the use of microfilm, have undoubtedly been major factors in the college librarians' apparent failure to recognize the potential place of film as a solution to at least some of their administrative problems.

In this paper I do not propose to assume any psychic powers in order to tell you what your problem is and how microfilm can solve it. No one but you can pretend to understand your immediate problems or propose their solution. Neither can I tell you all about microfilm and its reading equipment; and, if I could, it would be useless duplication of literature already in existence, from the hands of more competent authorities. My purpose shall be only to state one problem of library administration and, by presenting alternative solutions, to demonstrate that under certain conditions microfilm has a place in the college library.

\section{Newspapers}

Briefly stated, the problem is newspapers. Our files comprise the local papers, including the college paper, from I 847 to date, and the New York Times from I9I 3 to date. At least half are pulp paper. As in all such collections, the problem is inherently twofold; namely, the prevention of deterioration of the paper stock itself and the provision of adequate and accessible storage and reading room space.

The traditional solution of the first phase of the problem would be the preservation of the originals by some process, varying from the covering with Japanese tissue at a cost of seven or eight cents per sheet, to lamination with cellulose acetate at a cost of about fifteen to twenty cents per sheet. With an estimated minimum of I 75,000 pages, or 87,500 sheets, in the files of the local newspapers alone, the immediate cost to be anticipated would range from $\$ 6$ I 25 to $\$ 17,400$. These figures do not take into consideration the rebinding costs and the added storage space necessitated by the increased bulk resulting from any known preservative process. Nor are we, for the moment, even considering the overwhelming task of taking any steps toward processing the New York Times, I 9 I 3 to date.

In the second phase of our problem, we are confronted with an estimated total of 6250 cubic feet tied up in newspaper files, traffic, and reading room space, with all available shelf and building space already occupied.

\section{Space Requirements}

The New York Times and our local newspapers in bound form require thirtyfive cubic feet of shelf space annually. To provide adequate shelving and traffic space at this rate of expansion for a period of twenty-five years would require the immediate addition to our building of a room fifteen by twenty feet at an estimated cost of $\$ 3000$, or $\$$ I per cubic foot-and this without any regard to architectural continuity. Shelving would cost from $\$ 1000$ to $\$ 2000$, depending upon whether ordinary steel storage or roller type were purchased.

Summarizing briefly, if the foregoing solution were adopted, including processing of the local papers and the provision of building space and shelving for the next twenty-five years, an immediate expendi- 
ture of $\$ 10,125$ to $\$ 22,400$ would have to be made.

Microfilm presents the only alternative solution. It is with the adequacy and economy of this alternative that the remainder of this paper is concerned.

The first question with which we are confronted is that of the durability of microfilm. We know that the new safety microfilm is less subject to destruction by fire than is paper, in that the former will burn only so long as it is in contact with flame from another source. It is obvious that it is easier to provide fireproof storage for film than for the originals, which might require as much as 98 per cent more space. We are reasonably sure, according to the U.S. Bureau of Standards, ${ }^{4}$ that, stored under proper conditions of humidity, cellulose acetate ("safety") microfilm can be expected to last as long as the best rag paper.

\section{Legality of Film Copies}

Another question pertaining to film copies to which we must give some thought is that of the legality of such copies; in other words, are materials on microfilm

4 U.S. Bureau of Standards. Miscellaneous Publication MI62. Washington, Superintendent of Docu-

ments, I939. Broadman, have taken exception to the Bureau of Standards' report. The bone of contention, briefly stated, is that the bureau, while maintaining that nitrates in films are harmful, has at the same time nitrates in films are harmful, has at the same time
published the above findings as to the permanency of cellulose acetate film in which some traces of nitrates are to be found. In concluding, Dr. Broadman goes on to ask, ". . Is the Paper Section of the Bureau of Standards truly an agency for the standardization [of] scientific facts or merely a servant for the big [of] scientific facts or merely a servant for the big make the best of a bad situation since so many institutions, and even the United States government, have invested large sums in films?" I do not wish to invested large sums in films?" I do not wish to which has been raised by Dr. Broadman, who is him self the inventor and producer on a commercial basis of a process of paper preservation which is not without merit. This is primarily a question, however, for technicians. In the meantime we can at least be sure technicians. In the meantime we can at least be sure copies will outlast our old pulp paper, and should our successors discover that the films were deteriorating, new positives could be made at a minimum cost. preserved or merely reproduced? In the filming of certain types of material, especially those which might conceivably be referred to for legal purposes such as business records, vital statistics, or other archival and primary source materials, the admissibility of such copies as evidence, in the absence of the original document, has been considered. In an opinion handed down by the United States Court of Appeals in the case of the United States of America, Plaintiff, vs Martin T. Manton and George $M$. Spector, Defendants, it was held that such photographic records (in this case, of cancelled checks) constitute not secondary but primary evidence as proof of payment. ${ }^{5}$ This does not mean that there remains no further question of the legality of film copies, but as far as newspapers and perhaps other materials in the library are concerned, there would seem to be no reason for hesitation in discarding the originals for film copies in the interests of more efficient storage and preservation.

Having concluded that microfilm offered the legitimate medium for the preservation of newspaper files, our next problem was one of sources and costs of photography. Several alternatives were immediately apparent. First, the library might purchase outright or rent the necessary equipment from the Recordak Corporation and employ an operator. Second, a contract could be entered into with the Eastman subsidiary, under which the library would ship the materials to be photographed to the company's plant, where all of the work would be done. Third, we might find a professional operator properly equipped for microphotography and near enough to make it possible to set up a

\footnotetext{
6 "Legality of Micro-Film Records." Journal of Documentary Reproduction 3:79-80, Mar. 1940.
} 
camera in our building, or to whom we could get the materials to be filmed without elaborate packing and high transportation costs. Obviously, the criteria for choosing from the above methods must be the quality of work obtainable and costs.

\section{First Method Discarded}

The first of these methods was discarded because to amortize equipment costs would have raised the price of filming to a figure in excess of that received on bids from the commercial sources. In addition, if a library undertakes to do its own filming, it must assume the responsibility for good copies. And the statement of the $\mathrm{Re}$ cordak Corporation that it takes little or no experience to take microfilm pictures because the experience has been built into the equipment itself is only applicable in filming uniform materials in which there is no variation in the size or type of paper and the intensity of the impression from one sheet to the next. One authority has said "the reproduction or the control of tone values is as important in copying as it is in pictorial photography." 6 You will never realize this so well as when you have obtained a poor film copy of some longsought bit of source material.

As for the costs and quality of work to be expected from either of the commercial sources, we discovered that there was no appreciable difference between the two, and the deciding factor was purely that of convenience. Costs will be found to vary with the volume of work to be done and type of material to be photographed. For the filming of our local newspaper files a figure of two and one half cents per page, or a maximum of

nal of Downsend, Agnes. "Film Characteristics." Jour-
Documentary Reproduction $1: 346-53$, Fall I938.
$\$ 4375$ was estimated. This represents a saving of not less than 30 per cent over the cheapest possible preservation by any other means, and instead of an increase in bulk, would permit a 98 per cent reduction over the storage space now required. So far as the current and future files of the New York Times and the local paper are concerned, if obtained on film, the immediate need for an addition to our building would be obviated.

\section{Requisite Reading and Storage Equipment}

But microfilm of any material in the library makes requisite certain reading and storage equipment. Investigations in this direction led us to the conclusion that there was only one satisfactory all-purpose reading machine with the necessary simplicity of operation for library usage. I refer to the Recordak Library Film Reader, Model C, at a price of $\$ 380$, equipped with writing table. The superiority of this machine, except for reading short strips of film not on reels, is so obvious that we will not discuss it further here, except to warn that, if you plan to embark upon any extensive use of microfilm in your library, you must have a machine so easily operated as not to discourage patrons in their use of it.

To assure the greatest degree of permanency of microfilm, it must be stored under conditions of a constant humidity from 50 to 52 per cent. For this purpose there are two competitive steel filing cabinets on the market today; one, at a cost of \$125, the other, at a cost of $\$ 167.50$. The first of these depends for its humidity control upon an asbestos block to which water is added when the humidity gauge on the outside drops below 50 per cent. The more expensive of the cabinets, manufactured by Remington Rand, appears to be 
more adequately insulated and depends for its humidity control upon certain chemical crystals which maintain a constant humidity within the cabinet by giving off moisture when the humidity drops below 50 per cent and absorbing moisture when it rises above 52 per cent. For year-round usage in very dry climates, in any climate during that part of the year in which the building is heated, or in airconditioned buildings, the cheaper of these cabinets would seem to be adequate. However, in regions where during the spring, summer, and fall the prevailing humidity is in excess of 50 per cent, I do not see how any reduction can be effected within the water-controlled type of cabinet. The film capacity of both cabinets is the same, sufficient for sixteen years of the film edition of the New York Times. In other words, two of these cabinets, costing $\$ 335$, will house more of the Times on film than could be housed in original form in a $\$ 4000$ addition to our building.

\section{Microfilm for Newspaper Files}

By making use of microfilm the solution to the problem of our newspaper files requires a maximum expenditure of $\$ 5050$, as against some amount ranging from $\$ 10$, I 25 to $\$ 22,400$ by any other effective means of preservation and storage. Such figures present a picture that every college business officer and trustee will understand, and yet even for a problem as pressing as this $\$ 5000$ cannot often be readily conjured up from the income of the average small college. Our own experience, however, has demonstrated that the reading and storage equipment necessary for film, and probably the filming itself, holds more gift-appeal to alumni and other interested groups than long ranges of steel shelving.
Having acquired, by gift, a Recordak Model C reader, a Students Microfilm Reader, and one controlled humidity cabinet, our first step was to convert our subscription from the bound edition of the New York Times to the film edition, thereby immediately eliminating any need for the construction of a newspaper storage room. By these same acquisitions, the way is opened to a project for filming early files of the Beloit papers which we expect to get under way this year, with the financial aid of interested local persons and organizations. When that job is completed, we will have not only assured the continued existence of valuable source materials but will also have released one much-needed room, now used for storage, for other purposes, and last but not least, we will have made available hundreds of pounds of paper for national offense.

Moreover, with even this minimum of film reading and storage equipment, the library has opened the way for an investigation by the college of the possible efficiency and economy of preserving on film its archives from the business, registrar's, and dean's offices.

\section{Research in Colleges}

Still more important, the library has opened the door to this mysterious thing called research - which, for lack of library resources in the college, is supposed to be one of the distinguishing features between the college and university faculty. Even honors work may take on new significance. For now, armed with the Special Libraries Association's Directory of Microfilm Sources, the catalogs of Southwestern Microfilm, Incorporated, and other guides, many out-of-print and manuscript materials may be entitled to consideration for purchase. 